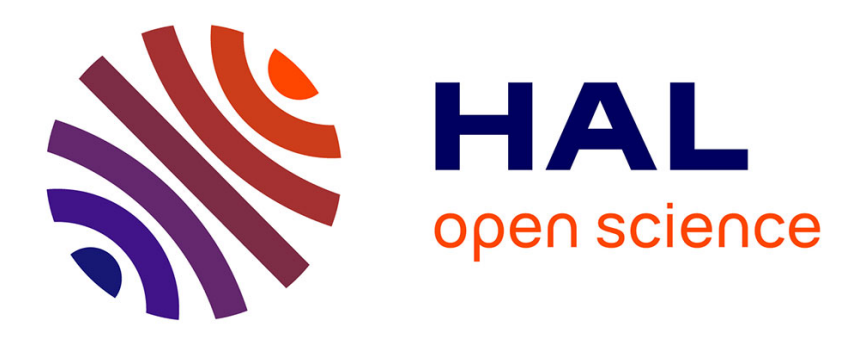

\title{
Ownership concentration and firm performance: Evidence from an emerging market
}

\author{
Irena Grosfeld
}

\section{To cite this version:}

Irena Grosfeld. Ownership concentration and firm performance: Evidence from an emerging market. 2006. halshs-00590485

\section{HAL Id: halshs-00590485 \\ https://shs.hal.science/halshs-00590485}

Preprint submitted on 3 May 2011

HAL is a multi-disciplinary open access archive for the deposit and dissemination of scientific research documents, whether they are published or not. The documents may come from teaching and research institutions in France or abroad, or from public or private research centers.
L'archive ouverte pluridisciplinaire HAL, est destinée au dépôt et à la diffusion de documents scientifiques de niveau recherche, publiés ou non, émanant des établissements d'enseignement et de recherche français ou étrangers, des laboratoires publics ou privés. 


\section{Paris-Jourdan Sciences Economiques \\ 48, BD JOURDAN - E.N.S. - 75014 PARIS \\ TEL. : 33(0) 143136300 - FAX : $33(0) 143136310$ \\ www.pse.ens.fr}

WORKING PAPER Nº 2006 - 18

Ownership concentration and firm performance:

Evidence from an emerging market

Irena Grosfeld

JEL Codes : D24, G32, L1, P2

Keywords : Ownership structure, corporate governance, human capital intensive firms 


\section{Introduction}

What are the characteristics of 'good' ownership structure? Does ownership structure matter for firm performance? Why certain firms have large block holders and others do not? Should the power of large shareholders be limited to avoid expropriation or encouraged to curb managerial discretion? These questions have been largely explored in corporate finance literature and we understand better now the intricacies of the relationship between ownership structure and firm performance.

But empirical evidence on the impact of shareholders with significant equity holdings on corporate performance remains ambiguous. Various authors using different samples of firms and different empirical strategies obtain different, difficult to compare and sometimes contradictory results. It is increasingly recognized that the problem in disentangling this relationship is largely due to the pervasive endogeneity of ownership which has to be taken into account in order to obtain unbiased results. But the existing empirical evidence also suggests that the relationship between ownership and performance may depend on the type of the firm and on the period of observation in the life of the firm.

The purpose of this paper is to explore more in details the determinants of ownership concentration and the relationship between ownership structure and firm value in the context of an economy undergoing important changes in its legal and regulatory framework, in macroeconomic policy and most of all, in its property rights allocation. Using a panel of firms listed on the Warsaw Stock Exchange (WSE) offers an unusual opportunity for this kind of investigation.

The Polish economy was exposed to radical institutional changes in the nineties. Privatization strategy in Poland was strongly influenced by the willingness to create appropriate ownership structure in privatized firms, i.e. to ensure that powerful block holders control the firm. A large portion of state-owned enterprises was privatized and the conditions for entry of new firms were significantly eased. Some of the privatized and newly created firms have entered the stock exchange established in 1991. These firms are likely to show a lot of heterogeneity. Their ownership structure is likely to be determined by the firm origin and for privatized firms by the method of privatization. New firms, when they become listed on the stock exchange are likely to have, at least during the initial years of listing, more concentrated ownership structure than privatized firms. Moreover, new firms established by their founders in a market friendly environment may require less ownership, financial and industrial restructuring than previously state-owned enterprises.

The sensitivity of firm performance to firm ownership structure is likely to vary across firms. It may also undergo important changes over time. Once firms are listed on the stock exchange, reallocation of ownership stakes becomes greatly facilitated. ${ }^{1}$

The first part of this paper is devoted to the exploration of the determinants of ownership concentration. Trying to understand why certain firms have large owners and others have dispersed ownership structure, I build on the extant literature and notably on Demsetz and Lehn (1985) and Himmelberg et al. (1999). The contribution of my paper to the literature consists in taking into account the importance of knowledge related activities. ${ }^{2}$ The idea is that analyzing the relationship between managers and shareholders requires different perspectives in firms belonging to the sector of "new economy" than in firms belonging to more traditional industries 
(Audretsch and Lehmann, 2002). In more 'mature' industries, it can be assumed that it is well understood what should be done and how and it is important to make sure that managers implement efficiently the objectives agreed on. In such conditions, the dominant concern is indeed about managerial shirking, laziness and laxity (Marshall, 1923). Such concern motivates the importance and high value of monitoring. In firms with strong human capital component, it is less clear what is the right strategy or the right project. Forcing managers to do a particular thing may be costly since shareholders may not know what the best thing to do is. In such highly uncertain environment, ('uncertain' in the sense of Knight), the crucial issue is less to make sure that the agent-manager realizes a given objective with a maximum effort than to incite the manager to search for the best project. ${ }^{3}$

Managers are more likely to show initiative if they have some latitude to make effort and undertake innovative actions. In Aghion and Tirole (1997) concentrated ownership provides incentives to monitor, but it also reduces the manager's initiative or incentive to acquire information. Recognizing the importance of managerial initiative is at the heart of the theory of Burkart et al. (1997). They argue that increased monitoring by shareholders may be costly because it may depress initiative displayed by managers: managers are less likely to be active if they know that shareholders are likely to interfere. So too much monitoring may negatively affect managerial initiative and profitable investment opportunities will be lost. Burkart et al. (1997) view firm ownership structure as an instrument to solve the trade-off between control and initiative. Through more dispersed ownership structure shareholders commit themselves to weaker intervention which makes managers confident enough that they will not be dispossessed of the benefits of their initiative.

The trade off between initiative and control may be particularly strong in firms belonging to highly technological sectors. In such firms, ownership concentration (reflecting the value of monitoring) is likely to be lower than in more traditional sectors. ${ }^{4}$ I examine whether ownership concentration is related to the importance of knowledge related capital by including a dummy for firms belonging to high technology sector.

I also use the importance of firm's "soft" capital, measured as the share of intangibles in fixed assets, as an additional proxy for the firm's specific uncertainty. ${ }^{5}$ Following Zeckhauser and Pound (1990), I expect that the higher the firm R\&D intensity, the more diffuse is the informational structure and the more difficult outside monitoring. Large shareholders are supposed to recognize the problem and, therefore ownership concentration is likely to be negatively related to soft capital intensity. ${ }^{6}$

The results show that the regression is able to explain on average about $25 \%$ of the variation in ownership concentration. They also confirm that firms belonging to highly technological sectors have more dispersed ownership structure. This effect is particularly noticeable in the sub-sample of 'new' firms which may be explained by the fact that high tech firms are almost exclusively 'new'.

In the second part of the paper I explore the relationship between ownership concentration and firm value. In pooled OLS regression higher ownership concentration improves firms' corporate value. When we take into account endogeneity of ownership, its impact on firm value becomes much stronger than in OLS regressions.

The results reported in this paper suggest that firm heterogeneity may significantly affect ownership concentration and its impact on firm value. They also confirm the need to take into account endogeneity of ownership but also the difficulty of doing it. The validity of chosen 
instruments should be carefully assessed and using alternative sets of instruments should be envisaged. Overall, the results yield a rather cautionary tale about one of the issues considered in corporate governance literature: "should the power of large shareholders be limited to avoid expropriation or encouraged to curb managerial discretion". Regulatory authorities should be very careful and avoid imposing constraints on the adjustment of firm ownership structure to firm specific characteristics.

Before I discuss these empirical results, in section 2 I briefly describe the relevant literature. In section 3 I present the data. Section 4 discusses the determinants of ownership concentration and section 5 the relationship between ownership and firm value. Conclusions are presented in section 6.

\section{Literature}

Following the early work by Berle and Means (1932) and until the eighties, the main concern of the literature on corporate governance was the conflict of interest between shareholders and managers (Jensen and Meckling, 1976). ${ }^{7}$ Ownership concentration (ensuring better monitoring), and managerial equity holdings (increasing managerial effort and decreasing perquisite consumption), were supposed to lead to better firm performance. An important empirical literature examining this prediction mainly focused on the relationship between managerial ownership and firm value. Following Stulz (1988) who predicted a concave relationship, several papers, including Morck et al. (1988), McConnell and Servaes (1990), Hermalin and Weisbach (1991), Holderness et al. (1999) found that low levels of managerial ownership increase firm value but at higher levels of managerial ownership firm value decreases. The results of these single-equation studies were interpreted as the evidence of managerial entrenchment beyond some threshold of insider ownership.

Since the 90s, careful observation of ownership structures across the world showed that dispersed shareholdings are much less frequent than expected and we observe instead a high degree of ownership concentration (La Porta et al., 1999; Becht and Roell, 1999). Consequently, the potential expropriation of the minority investors by the controlling owners became the main concern (Johnson et al., 2000, Faccio and Lang, 2002; Lehman and Weigand, 2000, Gugler and Weigand, 2003). It was recognized that large shareholders may be costly because they have other objectives than small shareholders and may expropriate the latter.

Other costs of excessive ownership concentration have been underlined in recent literature and several theories have been proposed to explain the ambiguity of the relationship between ownership concentration and firm performance. Holmstrom and Tirole (1993) explored the tradeoff between ownership concentration and liquidity which may affect the informational role of the stock market. It has been also stressed that high ownership concentration limits diversification and reduces owners' tolerance towards risk (Demsetz and Lehn, 1985; Admati et al., 1994; Bolton and von Tadden, 1998). Finally, Burkart et al. (1997) analyzed how in some circumstances the control imposed by strong owners on managers may be too severe, restraining their initiative and incentives.

An important strand of the literature focuses on the endogeneity of ownership structure in its relationship with firm performance. The initial argument about the endogeneity of ownership structure was formulated by Demsetz (1983). He argued that ownership structure is an outcome of shareholders' decisions. Maximizing the firm value may require a concentrated or a diffuse 
ownership structure. The trading of shares may reflect the desire of existing or potential owners to change their stakes. Following this important contribution, several papers explored empirically the impact of ownership structure on firm performance taking into account endogeneity of ownership. Demsetz and Lehn (1985), Hermalin and Weisbach (1991), Loderer and Martin (1997), Cho (1998), and Demsetz and Villalonga (2001) use a system of simultaneous equations and find no significant relationship between ownership and performance. Kole (1994) finds evidence of reverse causality, performance affecting ownership rather than the other way round.

Himmelberg et al. (1999) argue that endogeneity of ownership may be largely due to individual heterogeneity. Using firm fixed effects they find no significant relationship and conclude that shareholders choose ownership structure optimally. Interestingly, Khanna et al. (2005) find that Himmelberg et al. (1999) results of no correlation between managerial ownership and firm value in a fixed effect estimation are specific to the period considered. If the sample is extended over the next 10 years, the correlation turns out to be significant. Controlling for unobservable firm level heterogeneity was criticized by Zhou (2001) who argued that including fixed effects may not allow detecting an effect of ownership on performance even in it existed.

Gugler and Weigand (2003) consider simultaneously whether the largest shareholder's stake matters for the endogeneity/causality relation in addition to managerial ownership. Using IV techniques they find, for US and Germany, that insider ownership does not significantly affect performance as measured by the return on total assets. But the largest shareholder remains significant for firm performance even if they control for simultaneity. There is also some empirical evidence of a negative impact of large equity holders on firm performance. Lehmann and Weigand (2000), focusing on German corporations, find indeed a negative effect of ownership concentration on firm performance.

\section{Empirical strategy}

Before exploring the complex relationship between ownership and performance, I first look at the determinants of ownership concentration. It is important to understand how firm ownership structure varies across firms and how it is affected by the listing on the stock exchange. One of the hypotheses I want to test is whether ownership concentration is lower in firms with an important share of knowledge related activities. Investigating the determinants of ownership concentration will hopefully also provide us with the potential instruments for this variable.

Turning to the firm value equation, we know that the OLS results can be biased for two reasons: first, because of unobserved heterogeneity of firms which may be correlated with ownership concentration and firm performance; second, because of simultaneity and potential reverse causality between ownership and performance.

A solution to the problem of unobserved heterogeneity is the use of panel data. Himmelberg et al. (1999) used panel techniques to control for firm level fixed effects and found that the impact of managerial shareholding is not significantly different from zero. I obtained similar results in the sample of Polish firms studied in this paper: once unobservable firm level fixed effects are included in the regression, ownership concentration does not seem to affect firm performance anymore (results available on request).

Using a model with fixed effects to investigate the relationship between ownership and performance may be, however, misleading. Zhou (2001) argued that such approach may fail 
because it may not allow detecting an effect of ownership on performance even if it existed. ${ }^{8}$ Using fixed effects we focus on within rather than cross-sectional variations. But what appears crucial in investigating the relationship between ownership and performance is to understand whether in some firms higher ownership concentration may be more beneficial than in others. An additional argument against treating unobservable variables as fixed effects comes from the specificity of the sample considered in this study. In a transition economy like the Polish one in the period under examination, firms are exposed to profound industrial, managerial and financial restructurings. It makes questionable the assumption that firm specific characteristics do not change over time. ${ }^{9}$ Finally, fixed effects estimations are also costly because it is not possible to estimate coefficient on time-invariant variables.

Taking these arguments into account ${ }^{10} \mathrm{I}$ focus on the endogeneity due to the correlation between ownership and idiosyncratic errors in firm value equation. In order to investigate the relationship between ownership concentration and firm value, we have to consider not only the possibility that ownership concentration is likely to affect firm performance but also the possibility that ownership structure may depend on the value of the firm. The impact of performance on owners' decision to concentrate their holdings is a priori ambiguous. If shareholders believe they are able to create value and obtain benefits of control sufficiently large to override the cost of the effort and to compensate for the loss of benefits of diversification, they may be willing to increase their holdings in firms which have not yet capitalized their growth opportunities in the stock price. ${ }^{11}$ However, especially in emerging markets, with potentially high informational asymmetries, investors may also want to get a dominant position in a firm if they plan to extract value from the company: in that case they would prefer increasing their equity holdings in more profitable firms.

Consequently, the empirical strategy adopted in this paper will rely on estimating a model of simultaneous equations: in the first equation, the dependent variable is ownership concentration measured as the share of the voting rights of the largest shareholder (ownconc); in the second equation the dependent variable is firm performance measured as Tobin's Q (Q).

Ownconc $=\mathrm{f}(\mathrm{Q}$, firm characteristics, Zownconc $\mathrm{c}(\mathrm{t}), \mathrm{u}(\mathrm{it}))$

$\mathrm{Q}=\mathrm{f}$ (ownconc, firm characteristics, ZQ, c(t), e(it))

where c are year fixed effects, Zownconc is the vector of instruments for ownership concentration, ZQ is the instrument for Tobin's Q and u(it) and e(it) are white noise errors.

The obvious problem in estimating such system of equations is the problem of identification. We need at least two exogenous variables plausibly affecting only ownership concentration or firm value, not both of them. However, it is notoriously difficult to find valid instrumental variables for ownership concentration: most of the potential candidates are also likely to directly affect Tobin's Q. I will follow here two main studies in the relevant literature (Demsetz and Lehn, 1985; Himmelberg et al., 1999) and instrument ownership concentration in performance equation by using firm level volatility (its standard deviation and variance). This instrument has weaknesses but it was used previously in important contributions to the literature. Himmelberg et al. (1999) argued that stock price volatility is an acceptable although not perfect instrument for ownership structure; and that other potential candidates are probably worse because more likely to also affect Tobin's Q. Also see Demsetz and Lehn (1985).

Concerning the second equation, for Tobin's Q, I will use initial profitability as a predetermined variable for Tobin's Q. Initial profitability is calculated as a ratio of net profit to total assets averaged over the three years preceding the publication of the prospectus. Initial profitability is 
likely to affect firm performance; however, there is little chance that it affects ownership concentration

\section{Data}

Our sample includes all non-financial companies traded on the Warsaw Stock Exchange (WSE). ${ }^{12}$ The WSE was established in 1991 and for the last fifteen years has been developing rapidly. There were 8 listed firms in 1991 and 214 in 2003. Market capitalisation of the WSE grew steadily through the period reaching 21 percent in 2003.

The quality of the information on the listed firms is very good as the requirements of reporting and transparency on the Warsaw Stock Exchange are quite strict and comparable to those of Western European stock exchanges. ${ }^{13}$ The initial data base was created relying on published, audited accounts of balance sheets and income statements. It has been extended manually by including detailed information on ownership structure and the method of privatization. The information on ownership structure includes the identity of all shareholders holding more than the mandatory disclosure threshold of 5 percent of the shares and the percentage of cash flow rights and voting rights they hold. We were able to collect this ownership information for all years between 1991 and 2003, with the exception of 13 firms which were introduced to the WSE in 1991 and 1992: for these firms the Security and Exchange Commission (Komisja Papierow Wartosciowych) did not collect the ownership data in 1992 and 1993.

Our sample of listed firms allows distinguishing firms that were previously state-owned and firms, which can be considered as 'new' in the sense that they never belonged to the state and were created as private firms by their founders. In 2003 there were 90 new firms and 124 privatized firms. 30 firms were privatized through IPOs, 55 through direct sale, 13 through leveraged employee and managerial buyout, and finally 26 listed companies were privatized in the framework of the National Investment Funds programme (a version of mass privatization scheme). ${ }^{14}$ The average employment in our firms is 1233 employees (median 509), the average age is 32 (median 23) and the average number of years of listing is 4 (median 3).

Table 1 provides information on our sample for years $1991-2003$. The number of firms entering the stock exchange varies significantly over time and reflects the privatization process and the development of the WSE. Table 2 shows the characteristics of the firms in the sample in 2003. These firms have an average Tobin's Q of 1.30 and the largest owners control on average 43 percent of voting shares.

Table 3 compares privatized firms with new firms. The last column in the table provides statistics for testing the hypothesis of equal group means ( $t$-statistics). The table reveals that on average new firms are, as could be expected, smaller than privatized firms; they have higher Tobin's Q (1.50 versus 1.19$)$ and their controlling owners hold a significantly larger portion of voting rights ( $47 \%$ versus $41 \%$ ); they have more intangibles and have been listed for more years than privatized firms. The idiosyncratic risk (firm volatility)does not differ in a significant way between these two categories of firms.

The important advantage of this data base is that it makes possible observing the change in ownership structure of the firms over time: we can see how the introduction of the firms on the stock exchange and the years of listing affect their ownership structure. Two dimensions of ownership structure are taken into account: ownership concentration and the identity of the largest shareholder. I use the commonly used concentration measure which is the fraction of voting rights 
of the largest shareholder. Four groups of owners are identified: families, industrial firms, institutional investors, and the state.

Table 4 shows that ownership of companies becomes more dispersed with the number of years of listing. ${ }^{15}$ The average voting rights held by the largest shareholder decreases quite rapidly notably during the first three years of listing. When we look separately at privatized and 'new' ${ }_{16}$ firms, we can observe that the initial differences in ownership concentration disappear with time.

More detailed information on the evolution of the ownership structure can be found in table 5: it presents changes in ownership concentration by the type of largest owners during the first six years of listing. We can see that the most important changes took place in privatized firms in which the state was the largest shareholder: state's voting rights declined on average from $85 \%$ to $32 \%$ (the decrease of median values is even stronger). ${ }^{17}$ In firms in which the largest shareholders were families, firms or financial institutions the changes in ownership concentration were less spectacular.

\section{Determinants of ownership concentration}

Demsetz (1983) and Demsetz and Lehn (1985) were first to argue that in equilibrium ownership structure is determined endogenously, trading off costs and benefits of ownership concentration. They suggested that whether shareholders hold large or small portions of firm equity depends on specific firm's characteristics and on its contracting environment. Following Demsetz and Lehn, several author estimated ownership structure expanding the initial specification (see Himmelberg et al., 1999; Demsetz and Villalonga, 2001).

I follow here these studies using similar explanatory variables for ownership concentration, measured as the share of the voting rights of the largest shareholder; I also augment the previously used specification along the lines discussed in the introduction. In order to distinguish firms by the importance of knowledge related activities and check whether firms with stronger human capital component have more dispersed ownership structure, I use a dummy variable for firms belonging to highly technological industries. I rely on the Warsaw Stock Exchange classification of listed equities, which distinguishes the segment of innovative technologies. I also use the observable measure of intangible assets as it appears on the balance sheet as a proxy for firm's soft capital. Intangible assets include R\&D expenditures, acquired software, licenses, good will, etc.

Several control variables will be included in the regression for ownership concentration:

Size

In the existing empirical studies ownership concentration tends to be negatively affected by firm size (Demsetz and Lehn, 1985, Himmelberg et al. 1999). This result reflects probably wealth limitations (it is simply more costly to acquire large portion of equity in larger firms) and the concern with risk diversification. But size is also sometimes considered as a proxy for managerial discretion (Himmelberg et al., 1999); in that case we expect size will positively affect ownership concentration. Size may also be viewed by potential shareholders as a proxy for reputation. I measure size as the natural logarithm of the firm's sales. ${ }^{18}$ 


\section{Year dummies}

Year dummies are included to control for macroeconomic shocks common to all firms. The use of these dummies is particularly important in an economy undergoing profound institutional and systemic changes.

\section{Identity of shareholders}

Ownership concentration may depend on the identity of the equity holders. For instance, financial institutions are less likely to accumulate large portion of equity in a given company than an affiliated industrial firm. I distinguish four types of owners: family, the state (the Treasury, municipality or a government agency), financial institution (bank, insurance company or investment fund) and industrial firm. A firm is classified as being controlled by a family when there is an individual or a group of individual belonging to the same family who control the largest voting block of shares. I identify families relying on family surname. I also use a dummy if a foreign investor holds at least $20 \%$ of voting rights in firm's equity.

\section{Current profitability}

This variable, defined as net profit to sales, is often used in ownership equation ${ }^{19}$ as a proxy for agency problems.

\section{Volatility (risk)}

This is another proxy for agency problems. Demsetz and Lehn (1985), Himmelberg et al. (1999) and Demsetz and Villalonga (2001) motivate including risk as a determinant of ownership concentration by the principal agent theory: when the environment is more volatile, it is more difficult for shareholders to monitor managers but there are also more potential benefits from closer supervising the managers (they call it 'control potential'). When firm environment is relatively stable, the argument goes, shareholders have less difficulty to monitor managers. Consequently, it is expected that highly risky firms will have higher ownership concentration. However, Demsetz and Lehn (1985) and Aggarwal and Samwick (2003) also argue that beyond some threshold of idiosyncratic risk, investors may prefer to reduce their exposure. Following this argument I also suppose that the relation between risk and ownership concentration is concave.

I calculate each firm idiosyncratic risk using daily data of stock prices. The data on individual firm daily stock prices were collected from the data base provided by the Warsaw Stock Exchange. For each firm and for each year, I run a regression of firm's daily return on the market return. I use the residual standard deviation in the firm's return, i.e. the standard deviation in the firm's return after the effect of its covariation with the market is taken out.

\section{Number of years of listing}

The longer the firm's shares are traded on the stock exchange, the more is known about them and the potential agency problems become less important. It is therefore likely that ownership structure, which can be considered as an instrument of control and an answer to information asymmetries, will become less concentrated.

\section{Firm value}

Firm value will be included in the equation for ownership concentration to deal with the potential problem of reverse causality: it has been argued that although ownership may affect performance, ownership structure may also be affected by the quality of the firm. ${ }^{20}$ The issue of endogeneity of firm value in ownership concentration equation will be addressed later on, in a simultaneous equations framework. Here, I simply look at robust correlations but to alleviate the problem of endogeneity, use lagged values of firm value. 


\section{Industry affiliation}

Besides distinguishing companies from the segment for innovative technologies, I follow Demsetz and Lehn (1985) and keep dummies for utilities and media. Demsetz and Lehn (1985) suppose that regulated firms (utilities) are less concentrated because regulatory constraints may be a substitute for shareholder monitoring. They also distinguish firms by the potential of control they offer and expect this potential is particularly high in the case of media industry.

\section{Privatization method}

Particular privatization method may significantly affect ownership structure of privatized firms, especially during the initial years of listing. For instance, firms privatized in the framework of the Polish mass privatization scheme had initially a uniform ownership structure (the largest shareholder holding 33 percent of shares). ${ }^{21}$ For instance, firms privatized in the framework of National Investment Funds programme (a form of mass privatization scheme) had at the time of privatization a uniform ownership structure (the leading NIF had 33\% of shares, $27 \%$ of shares were uniformly distributed among 14 NIFs, the employees had $15 \%$ and the State $25 \%$ of shares). In firms privatized through IPO the state has initially an important stake. New firms, when they enter the stock exchange, are often owned by their founders and are likely to have, at least during the first years of listing, a rather more concentrated ownership structure than privatized firms. I classify privatized firms by four privatization methods: IPO, private sale, employee and managerial buy out, or mass privatization scheme (mpp).

Consequently, I use the following model to estimate ownership concentration, defined as the logistic transformation of the share of the voting rights of the largest shareholder (Lvote1) ${ }^{22}$ :

$$
\begin{aligned}
& \text { Lvote }_{i t}=\beta_{0}+\beta_{1} \text { size }_{i t}+\beta_{2} \text { current_profitability }+\beta_{3} \text { volatility }_{i t}+\beta_{4} \text { volatility }_{i t}+ \\
& \beta_{5} \text { listing }_{i t}+\beta_{6} \text { family }_{i t}+\beta_{7} \text { fininst }_{i t}+\beta_{8} \text { state }_{i t}+\beta_{9} \text { foreign } 20_{i t}+ \\
& \beta_{10} \text { intangibles }_{i t}+\beta_{11} Q_{i t-1}+\beta_{12} \text { media }_{i}+\beta_{13} \text { utilities }_{i}+\beta_{14} \text { hightech }_{i}+ \\
& \beta_{15} \mathrm{mpp}_{i}+\beta_{16} \mathrm{embo}_{i}+\beta_{17} \mathrm{IPO}+\gamma_{t}+\varepsilon_{i t}
\end{aligned}
$$

where $\mathrm{i}$ and $\mathrm{t}$ represent the firm and time respectively; size is the logarithm of total sales; profitability is defined as net profits on sales; volatility is defined as standard error of the residual of CAPM equation per year; listing represents the number of years since the first listing; family, finist, state equal to one if, respectively, the largest share of voting rights is held by a member of a family, a financial institution or the state and zero otherwise (firm is a reference group); foreign20 is a dummy equal to one if a foreign investor holds at least $20 \%$ of shares of firm equity; intangibles is the share of intangible assets in fixed assets; Q is defined as the ratio of the market value of equity plus total debt divided by the book value of total assets; media and utilities equal one if the firm belongs respectively to utilities or media industry, and zero otherwise; high-tech equals to one if the firm belongs to the segment of high technology and zero otherwise; mpp, embo and IPO are dummy variables equal one if the firm was privatized, respectively, in the framework of the mass privatization programme, through managerial and employee leveraged buy-out or through public share offering (private sale is a reference group); finally, $\gamma_{t}$ represent year dummies (to control for common macroeconomic shocks); $\varepsilon_{i t}$ is a white-noise error.

The results of the OLS regressions are presented in table 6. In columns (1) - (5) the results refer to the whole sample. We can observe how including additional variables increases the 
explanatory power of the regression which eventually (column (5) is quite high: we can explain $26 \%$ of the variation in ownership concentration.

Concerning the measures of knowledge related capital, the results give support to the idea that ownership concentration varies inversely with intangibles and is significantly lower in firms belonging to the sector of high technology. Interestingly, even after controlling for high technology sector, I get significant result on the coefficient of intangibles. This result is quite strong as it could be expected that much of the variation in 'soft capital' could be explained by the industry dummy.

The impact of firm's idiosyncratic risk on ownership concentration is, as expected, positive. In some regressions the results show that risk affects ownership concentration in a non-linear way.

In columns (6) and (7) I perform separate regressions of ownership concentration on identical sets of explanatory variables for two smaller samples of privatized and new firms. We can see that the significant result on the proxies for uncertainty, obtained in the entire sample, is driven by new firms: intangibles and the dummy for the segment of high technology are insignificant in privatized firms. This can be explained by the fact that only one privatized firm ( 14 observations) belongs to the sector of high technology and intangibles are on average three times higher in 'new' firms than in privatised firms. It turns out that the regression is able to explain much better ownership concentration in privatized than in new firms: in the former $\mathrm{R}^{2}$ equals 0.33 and the latter 0.21. This suggests that 'new' firms are closer to an 'equilibrium' ownership structure. In privatized firms more adjustment is probably needed. In the last column (8), adding privatization methods as additional explanatory variables increases $\mathrm{R}^{2}$. The way firms were privatized significantly affects their ownership concentration, especially during the initial years of listing. ${ }^{23}$

Table 6 does not give support to reverse causality hypothesis: the coefficient of the firm value is insignificant. But to properly deal with the issue of reversed causality, we need a simultaneous equations framework (see section 5 below).

\section{Ownership concentration and firm value.}

In order to test the impact of ownership concentration on firm value, I estimate the system of simultaneous equations in which the first equation is the equation (1) for ownership concentration and the second equation is the following equation (2) for Tobin's Q:

$$
\begin{aligned}
& Q_{i t}=\delta_{0}+\delta_{1} \text { Lvote }_{1 i t}+\delta_{2} \text { initial_profitability }+\delta_{3} \text { current_profitability }{ }_{i t}+\delta_{4} \text { size } e_{i t} \\
& +\delta_{5} \text { listing }_{i t}+\delta_{6} \text { family }_{i t}+\delta_{7} \text { fininst }_{i t}+\delta_{8} \text { state }_{i t}+\delta_{9} \text { foreign20 }_{i t}+\delta_{10} \text { intangibles }{ }_{i t} \\
& +\delta_{11} \text { media }+\delta_{12} \text { utilities }+\delta_{13} \text { hightech }+\delta_{14} m p p+\delta_{15} \mathrm{embo}+\delta_{16} \mathrm{IPO}+\lambda_{t}+\boldsymbol{\varepsilon}_{\text {it }}
\end{aligned}
$$

where $\mathrm{i}$ and $\mathrm{t}$ represent the firm and time respectively; $\mathrm{Q}$ is defined as the ratio of market value of equity plus book value of total debt to book value of total assets; Lvotel is defined as the logistic transformation of the percentage voting rights held by the largest shareholders; initial profitability is the ratio of net profit to total assets averaged over the three years preceding the publication of the prospectus; current profitability is defined as net profit to sales; size is the logarithm of total sales; family, finist and state are dummy variables equal to one if, respectively, the largest share of voting rights is held by a member of a family, a financial institution or the state (firm is a reference group); foreign 20 is a dummy variable equal to one if a foreigner holds at least $20 \%$ of firm equity, and zero otherwise; intangibles is the share of intangible assets in fixed assets; media, 
utilities and high tech represent dummy variables for the three industries; mpp, embo and IPO are dummy variables equal one if the firm was privatized, respectively, in the framework of the mass privatization programme, through managerial and employee leveraged buy-out or through public share offering (private sale is a reference group); $\lambda_{t}$ represent year dummies (to control for common macroeconomic shocks); and $\varepsilon_{i t}$ is a white-noise error.

The necessary conditions for identification of such a simultaneous equations system are met because we include exogenous variables plausibly affecting only ownership concentration or firm value, not both of them. In the first equation, standard deviation and variance of volatility are used as instruments. These instruments were used in the literature and I follow this strategy for the sake of comparability.

Concerning the second equation, initial profitability, i.e. average firm profitability before it is listed on the stock exchange, is likely to affect firm performance; but there is little chance that it directly affects ownership concentration. The presence of current profitability in ownership concentration equation makes this identifying restriction assumption even more convincing.

Let me note that capital structure does not appear in this model. Debt is clearly one of the mechanisms of control that should be taken into account in a complete system of equations. However, including it would require estimating a much bigger system of equations taking into account a two-way relation of debt and performance and the relation between debt and ownership structure (see Loderer and Martin, 1997). This will certainly be one of the extensions of this paper.

In another specification not reported here, I have also explored the impact of dual class shares on firm value. Firm with such explicit separation of ownership and control may have important agency problems and may be less valuable than firms in which voting rights are equal cash flow rights. ${ }^{24}$ Claessens et al. (2002) found indeed in their study of Asian firms that firm value decreases when the control rights of the largest shareholder exceed its cash flow rights. Lins (2002) found that this effect is significant in countries with low shareholder protection. In the sample studied in this paper the coefficient of the dummy variable indicating for each firm if it issues dual-class shares turned out to be insignificant. ${ }^{25}$

In table 7, I report the results of OLS and of the second stage of 2SLS regressions for Tobin's Q.

${ }^{26} \mathrm{I}$ am mainly interested in the coefficient of ownership concentration $\delta_{l}$, other variables being used to control for various observable firm characteristics. For instance, the identity of the largest owner is included because different owners may have different incentives and capacities to perform efficient monitoring. So the relationship between concentrated ownership and firm performance may be sensitive to the type of the controlling shareholder. In the case of transition economies, it was notably argued that foreign investors bringing about their competence and the knowledge of market economy might have important positive effect on firm performance ${ }^{27}$ Let us note that in the sample of Polish firms considered in this paper the impact of foreign investors on firm value remain ambiguous.

We can observe that the increase in the share of the largest owner positively affects firm value and that this result in OLS regression is driven by the sub-sample of privatized firms (in 'new' firms, the coefficient of ownership concentration is not significantly different from zero). Durbin$\mathrm{Wu}$-Hausman test of the endogeneity of ownership concentration does not allow rejecting the hypothesis of the correlation between ownership concentration and the error term. Therefore, in columns (5) - (7) I present the results for the 2SLS. We can see that after controlling for 
endogeneity, the impact of ownership concentration on Tobin's Q is stronger as compared with OLS results. ${ }^{28}$

\section{Conclusions}

The main findings of this paper are as follows. Concerning the determinants of ownership concentration, the empirical results give support to the hypothesis that firms belonging to the sector of high technology have lower ownership concentration. The results reveal great heterogeneity across firms and over time. In 'new' firms, more similar to 'normal' firms in developed market economies, the impact of firm's specific uncertainty proxied by the importance of knowledge related activities is important. In privatized, previously state-owned firms, ownership concentration is highly sensitive to the legacy of privatization methods: important explanatory variables during the early years of listing, they loose, however, their significance after a couple of years. This suggests that shareholders progressively adjust their ownership structure to firm specific constraints and the requirements of firm environment. When firm's ownership structure approaches an 'equilibrium' level, it becomes more sensitive to variables representing firm specific risk and uncertainty.

In the case of privatised firms, OLS regression does not give consistent results and we have to take into account the endogeneity of ownership concentration. Consequently I estimate a system of simultaneous equations, in which ownership is the dependent variable in the first equation and firm value is the dependent variable in the second equation. It turns out that the impact of ownership on performance is even stronger when we control for the endogeneity of ownership.

More generally, answering the question what the characteristics of 'good' ownership structure are may depend on the underlying theory of the firm. The initial view of the advantages of ownership concentration in joint stock companies characterized by the separation of ownership and control was determined by the concern about the opportunistic behavior of managers. Far from being considered as entrepreneurs, managers of large corporations became even treated as civil servants: Schumpeter (1943) argued that the entrepreneurial function became obsolete because of the routinization of innovation. The growing importance of knowledge and human capital in the operation of firm shifts the focus of concern: excessive ownership concentration may stifle managerial initiative. This may be particularly true, and the results obtained in this paper support this hypothesis, in firms with high share of knowledge related activities. 
* I am grateful to Thierry Tressel, Philippe Aghion and Laszlo Halpern for their comments and suggestions and to Malgorzata Kalbarczyk for excellent research assistance. Financial support of the Japan Europe Cooperation Fund through the EBRD research program on "Institutional Development and International Integration: Strategies for Catch-up Growth and EBRD Operations" is gratefully acknowledged.

\section{References}

Acemoglu, D., Aghion, Ph., and Zilibotti, F. (2002), Vertical integration and distance to frontier. NBER Working Paper $n^{\circ} 9191$.

Admati, A., Pfleiderer, P., and Zechner, J. (1994), Large shareholder activism, risk sharing and financial market equilibrium. Journal of Political Economy, 102: 1097-1130.

Aggarwal, R. K., and Samwick, A. A. (2003), Why do managers diversify their firms? Agency reconsiderations. Journal of Finance 58 (1), 71-118.

Aghion, Ph., and Tirole, J. (1997), Formal and real authority in organizations. Journal of Political Economy. 55: 1-27.

Audretsch, D. B. and Lehmann, E. (2002), Does the new economy need new governance? Ownership, knowledge and performance. CEPR Discussion Paper ${ }^{\circ} 3626$.

Becht, M., and Röell,A. (1999), Blockholdings in Europe: An International comparison. European Economic Review 43: 1049-1056.

Berle, A., and Means, G. (1932), The Modern Corporation and Private Property. New York: Commerce Clearing House.

Bolton, P., and Von Tadden, E.L. (1998), Blocks, liquidity and corporate control. Journal of Finance, 53 (1): 1-25.

Boubakri, N., Cosset, J.-C., and Guedhami O. (2005), Postprivatization corporate governance: The role of ownership structure and investor protection. Journal of Financial Economics, 76, 369-399.

Burkart, M., Gromb, D. and Panunzi, F. (1997), Large shareholders, monitoring and the value of the firm. Quarterly Journal of Economic 112: 693-728.

Carlin, W. and Mayer, C. (2003), Finance, investment and growth. Journal of Financial Economics, 69 (1): 191-226.

Cho, M-H. (1998), Ownership structure, investment and the corporate value: an empirical analysis, Journal of Financial economics, 47: 103-121.

Claessens, S., Djankov, S., Fan, J., and Lang L. (2002), Disentangling the incentive and entrenchement effects of large shareholders. Journal of Finance. 57 (6): 2741-2771 
Demsetz, H (1983), The structure of ownership and the theory of the firm, Journal of Law and Economics. 26: 375-390.

Demsetz, H. and Lehn K. (1985), The structure of ownership: Causes and consequences. Journal of Political Economy 93 (6): 1155-1177.

Demsetz, H. and Villalonga, B. (2001), Ownership structure and corporate performance. Journal of Corporate Finance 7 (3): 209-233.

Faccio, M. and Lang, L.H.P. (2002), The ultimate ownership of Western European corporations. Journal of Financial Economics 65: 365-395.

Glaeser, E., Johnson, S. and Shleifer, A. (2001), Coase versus the Coasians. Quarterly Journal of Economics 116 (3): 853-899.

Grosfeld, I and Hashi, I. (2005), The emergence of large shareholders in mass privatized firms: Evidence from Poland and from the Czech Republic. PSE Working Paper $n^{\circ} 2005-01$.

Grosfeld, I. and Roland, G. (1996), Defensive and strategic restructuring in Central European enterprises. Journal of Transforming Economies and Societies 3 (4): 21-46.

Gugler, K. and Weigand, J. (2003), Is ownership really endogenous? Applied Economics Letters 10: $483-486$.

Helwege J., Pirinsky, C. and Stulz, R.M. (2005), Why do firms become widely held? An Analysis of the dynamics of corporate ownership. NBER Working Paper $n^{\circ} 11505$.

Hermalin, B. and Weisbach, M. (1991), The effects of board composition and direct incentives on firm performance. Financial Management 20: 101-112.

Himmelberg, C.P., Hubbard, R.G. and Palia, D. (1999), Understanding the determinants of managerial ownership and the link between ownership and performance. Journal of Financial Economics 53: 353-384.

Holderness, C., Kroszner, R. S., and Sheehan, D. (1999). "Were the good old days that good?: Changes in managerial stock ownership since the Great Depression," Journal of Finance 54 (2): 435-469.

Holmström, B., and Tirole, J. (1993), Market liquidity and performance monitoring. Journal of Political Economy 51, pp.678-709.

Jensen, M., and Meckling, W. (1976), Theory of the firm: Managerial behavior, agency costs and ownership structure. Journal of Financial Economics 3: 305-360.

Johnson, S., La Porta, R., Lopez-de-Silanes, F., and Shleife,r A. (2000), Tunnelling. American Economic Review 90 (2): 22-27 (May).

Kahn, C., and Winton, A. (1998), Ownership structure, speculation and shareholder intervention. Journal of Finance 53 (1): 99-129. 
Klapper, L.F., Laeven, L,. and Love, I. (2005), What drives corporate governance reform? Firm level evidence from Eastern Europe. World Bank Policy Research Working Paper $n^{\circ} 3600$.

Kole, S. (1993), Managerial ownership and firm performance: incentives or rewards? Working paper 93-19, Rochester, NY, Bradley Policy Research Center.

Pindado, J., and De la Torre Ch. (2004), Why is ownership endogenous? Applied Economic Letters 11(14): 901-904.

La Porta, R., Lopez-de-Silanes, F., and Shleifer, A. (1999), Corporate Ownership Around the World. Journal of Finance 54 (2): 471-517.

Lehmann E., and Weigand, J. (2000), Does the governed corporation perform better? Governance structures and corporate performance in Germany. European Economic Review 4: 157-195.

Lins K.V. (2002), Equity ownership and firm value in emerging markets. The Journal of Financial and Quantitative Analysis,

Loderer, C., and K., Martin (1997), Executive ownership and performance: tracking faint traces. Journal of Financial Economics 45: 223-255.

McConnell, J., and Servaes, H. (1990), Additional evidence on equity ownership and corporate value. Journal of Financial Economics 27 (2): 595-612.

Morck, R., Shleifer, A. and Vishny, R. (1988), Management Ownership and Market Valuation: An Empirical Analysis. Journal of Financial Economics 20: 293-315.

Prendergast, C. (2002), The tenous trade-off between risk and incentives. Journal of Political Economy 110 (5): 1071-1102.

Rajan, R.G., and Zingales, L. (2000), The governance of the new enterprise. in Corporate Governance (X. Vives, ed.). Cambridge University Press.

Shleifer, A., and Vishny, R. (1997), A survey of corporate governance. Journal of Finance 52: 737-783.

Stulz R.M. (1988), Managerial control of voting rights: Financing policies and the market for corporate control. Journal of Financial Economics 20 (1): 25-54.

Zeckhauser, R., and J., Pound (1990), Are large shareholders effective monitors? An investigation of share ownership and corporate performance, in Asymmetric Information, Corporate Finance, and Investment (Hubbard R. G. ed.). IL: University of Chicago Press: 149-180.

Zhou, X. (2001), Understanding the determinants of a managerial ownership and the link between ownership and performance: a comment. Journal of Financial Economics 62: 559-571.

Zingales, L. (2002), In search of new foundation. Journal of Finance 55: 1623-1653. 


\section{Table 1: Description of the sample: number of new and privatised firms}

Description of the sample of non-financial firms listed on the Warsaw Stock Exchange used in this study: distribution of listed firms included in the sample by year and the origin of the firm (new versus privatized). The number of observations says for how many firms we have data on the ownership structure; financial data may be missing for some of the observations.

\begin{tabular}{crrr}
\hline Year & $\begin{array}{c}\text { Number } \\
\text { of } \\
\text { observations }\end{array}$ & $\begin{array}{c}\text { Number of } \\
\text { privatized } \\
\text { firms }\end{array}$ & $\begin{array}{c}\text { Number of } \\
\text { new } \\
\text { firms }\end{array}$ \\
\hline & & & \\
1991 & 8 & 8 & 0 \\
1992 & 5 & 5 & 0 \\
1993 & 5 & 4 & 1 \\
1994 & 34 & 31 & 3 \\
1995 & 49 & 42 & 7 \\
1996 & 66 & 52 & 14 \\
1997 & 197 & 140 & 57 \\
1998 & 214 & 148 & 66 \\
1999 & 224 & 151 & 73 \\
2000 & 234 & 146 & 88 \\
2001 & 234 & 144 & 90 \\
2002 & 229 & 139 & 90 \\
2003 & 214 & 124 & 90 \\
& & & \\
\hline
\end{tabular}




\section{Table 2. Descriptive statistics}

Characteristics of the sample of non-financial firms listed on the Warsaw Stock Exchange; 2003

\begin{tabular}{|c|c|c|c|c|}
\hline Variables & Definition & Mean & Median & $\begin{array}{l}\text { Standard } \\
\text { Deviation }\end{array}$ \\
\hline Tobin's Q & $\begin{array}{l}\text { (market value of equity }+ \text { book } \\
\text { value of total debt)/ book value } \\
\text { of total assets }\end{array}$ & 1.30 & 0.99 & 0.97 \\
\hline $\begin{array}{l}\text { Initial } \\
\text { profitability }\end{array}$ & $\begin{array}{l}\text { Average net profit/total assets, } \\
\text { for the years preceding the } \\
\text { publication of the prospectus }\end{array}$ & 0.22 & 0.19 & 0.20 \\
\hline $\begin{array}{l}\text { Ownership } \\
\text { concentration }\end{array}$ & $\begin{array}{l}\text { Share of the voting rights of } \\
\text { the largest shareholder }\end{array}$ & 0.43 & 0.40 & 0.23 \\
\hline Firm size & Logarithm of total sales & 11.10 & 11.26 & 2.07 \\
\hline $\begin{array}{l}\text { Years of } \\
\text { listing }\end{array}$ & $\begin{array}{l}\text { Number of years since the first } \\
\text { listing }\end{array}$ & 5.57 & 5.0 & 2.66 \\
\hline Intangibles & $\begin{array}{l}\text { The share of intangible assets } \\
\text { in fixed assets }\end{array}$ & 0.02 & 0.003 & 0.04 \\
\hline $\begin{array}{l}\text { Operating } \\
\text { income }\end{array}$ & Net profit/sales & -0.34 & 0.02 & 3.88 \\
\hline Volatility & $\begin{array}{l}\text { Standard error of the residual } \\
\text { of CAPM equation }\end{array}$ & 3.70 & 3.35 & 2.06 \\
\hline
\end{tabular}




\section{Table 3: Differences in means of the main characteristics between privatized and new firms}

Characteristics of the sample of privatized and 'new' non-financial firms listed on the Warsaw Stock Exchange; 2003. See table 2 for the definition of the variables. The last column provides the t-statistics for the differences in means between privatized and 'new' firms. Significance at the $1 \%, 5 \%$, and $10 \%$ level is denoted $* * *, * *$, and $*$, respectively.

\begin{tabular}{lccc}
\hline Variable & Privatized & New & $t$-statistics \\
\hline Tobin's Q & 1.19 & 1.50 & $-2.07^{* *}$ \\
Initial profitability & 0.21 & 0.26 & -1.45 \\
$\begin{array}{l}\text { Ownership } \\
\text { concentration }\end{array}$ & 0.41 & 0.47 & $-1.87^{*}$ \\
Firm's size & 11.36 & 10.79 & $1.98^{* *}$ \\
Years of listing & 6.48 & 4.14 & $7.46^{* * *}$ \\
Intangibles & 0.01 & 0.03 & $-2.76^{* * *}$ \\
Operating income & 0.52 & -0.11 & -0.74 \\
Volatility & 3.92 & 3.33 & $1.80^{*}$ \\
\hline
\end{tabular}




\section{Table 4: The change in ownership concentration in listed firms by their origin (privatized/new)}

The table presents summary statistics on ownership concentration measured as the share of the voting rights of the largest shareholder in our sample of non-financial firms listed on the Warsaw Stock Exchange between 1991 and 2003. The first 8 years of listing are reported. Ownership data before the first listing comes from the offering prospectuses. $\mathrm{N}$ represents the number of observations

\begin{tabular}{|c|c|c|c|c|c|c|c|c|c|}
\hline \multirow[b]{2}{*}{ Sample } & \multicolumn{9}{|c|}{ Voting rights of the largest shareholder by the number of years of listing } \\
\hline & Prospectus & $\begin{array}{c}1 \\
\text { year }\end{array}$ & $\begin{array}{c}2 \\
\text { years }\end{array}$ & $\begin{array}{c}3 \\
\text { years }\end{array}$ & $\begin{array}{c}4 \\
\text { years }\end{array}$ & $\begin{array}{c}5 \\
\text { years }\end{array}$ & $\begin{array}{c}6 \\
\text { years }\end{array}$ & $\begin{array}{c}7 \\
\text { years }\end{array}$ & $\begin{array}{c}8 \\
\text { years }\end{array}$ \\
\hline $\begin{array}{c}\text { All } \\
\text { Mean } \\
\text { Median } \\
\text { N }\end{array}$ & $\begin{array}{c}0.5286 \\
0.4668 \\
257\end{array}$ & $\begin{array}{c}0.5005 \\
0.43 \\
257\end{array}$ & $\begin{array}{c}0.4070 \\
0.34 \\
234\end{array}$ & $\begin{array}{c}0.3982 \\
0.33 \\
220\end{array}$ & $\begin{array}{c}0.4206 \\
0.3338 \\
221\end{array}$ & $\begin{array}{c}0.4323 \\
0.3509 \\
206\end{array}$ & $\begin{array}{c}0.4123 \\
0.3518 \\
183\end{array}$ & $\begin{array}{c}0.3949 \\
0.34 \\
157\end{array}$ & $\begin{array}{c}0.3725 \\
0.325 \\
103\end{array}$ \\
\hline $\begin{array}{l}\text { Privatized } \\
\text { Mean } \\
\text { Median } \\
\text { N }\end{array}$ & $\begin{array}{c}0.5177 \\
0.4195 \\
146\end{array}$ & $\begin{array}{c}0.4894 \\
0.3651 \\
148\end{array}$ & $\begin{array}{c}0.3631 \\
0.329 \\
137\end{array}$ & $\begin{array}{c}0.3618 \\
0.3202 \\
138\end{array}$ & $\begin{array}{c}0.3878 \\
0.3299 \\
143\end{array}$ & $\begin{array}{c}0.4033 \\
0.3291 \\
140\end{array}$ & $\begin{array}{c}0.3908 \\
0.3333 \\
128\end{array}$ & $\begin{array}{c}0.3960 \\
0.345 \\
118\end{array}$ & $\begin{array}{c}0.3750 \\
0.3252 \\
80\end{array}$ \\
\hline $\begin{array}{c}\text { New } \\
\text { Mean } \\
\text { Median } \\
\text { N }\end{array}$ & $\begin{array}{c}0.5428 \\
0.49 \\
111\end{array}$ & $\begin{array}{c}0.5156 \\
0.4738 \\
109\end{array}$ & $\begin{array}{c}0.4690 \\
0.4521 \\
97\end{array}$ & $\begin{array}{c}0.4595 \\
0.4168 \\
82\end{array}$ & $\begin{array}{c}0.4807 \\
0.47 \\
78\end{array}$ & $\begin{array}{c}0.4938 \\
0.5 \\
66\end{array}$ & $\begin{array}{c}0.4625 \\
0.4396 \\
55\end{array}$ & $\begin{array}{c}0.3914 \\
0.3338 \\
39\end{array}$ & $\begin{array}{c}0.3638 \\
0.3236 \\
23\end{array}$ \\
\hline
\end{tabular}


Table 5: The change in ownership concentration in listed firms by their origin and identity of the largest owner

The table presents summary statistics on the change in ownership concentration (during the first six years of listing) measured as the share of the voting rights of the largest shareholder in a sample of non-financial firms listed on the Warsaw Stock Exchange between 1991 and 2003. I consider four types of owners: families, financial institutions, industrial firms and the government. $\mathrm{N}$ represents the number of observations.

\begin{tabular}{|c|c|c|c|c|c|c|c|}
\hline \multirow{2}{*}{$\begin{array}{l}\text { Identity of the } \\
\text { largest equity } \\
\text { holder }\end{array}$} & \multicolumn{7}{|c|}{ Voting rights of the largest shareholder during the first six years of listing } \\
\hline & Prospectus & 1 year & 2 years & 3 years & 4 years & 5 years & 6 years \\
\hline \multicolumn{8}{|l|}{ Family } \\
\hline \multicolumn{8}{|l|}{ Privatized } \\
\hline Mean & 0.297 & 0.309 & 0.270 & 0.289 & 0.325 & 0.341 & 0.328 \\
\hline Median & 0.284 & 0.284 & 0.226 & 0.225 & 0.250 & 0.302 & 0.305 \\
\hline $\mathrm{N}$ & 14 & 14 & 13 & 17 & 21 & 25 & 26 \\
\hline \multicolumn{8}{|l|}{ New firms } \\
\hline Mean & 0.56 & 0.522 & 0.478 & 0.438 & 0.435 & 0.455 & 0.457 \\
\hline Median & 0.5 & 0.480 & 0.451 & 0.384 & 0.361 & 0.450 & 0.42 \\
\hline $\mathrm{N}$ & 69 & 70 & 53 & 47 & 42 & 35 & 29 \\
\hline \multicolumn{8}{|l|}{$\begin{array}{l}\text { Financial } \\
\text { institution }\end{array}$} \\
\hline \multicolumn{8}{|l|}{ Privatized } \\
\hline Mean & 0.310 & 0.293 & 0.267 & 0.271 & 0.292 & 0.276 & 0.277 \\
\hline Median & 0.33 & 0.33 & 0.299 & 0.294 & 0.269 & 0.254 & 0.250 \\
\hline $\mathrm{N}$ & 55 & 52 & 59 & 47 & 40 & 33 & 28 \\
\hline \multicolumn{8}{|l|}{ New firms } \\
\hline Mean & 0.264 & 0.295 & 0.349 & 0.281 & 0.437 & 0.425 & 0.270 \\
\hline Median & 0.179 & 0.198 & 0.335 & 0.263 & 0.370 & 6.274 & 0.231 \\
\hline $\mathrm{N}$ & 8 & 9 & 8 & 6 & 5 & 4 & 3 \\
\hline \multicolumn{8}{|l|}{ Firm } \\
\hline \multicolumn{8}{|l|}{ Privatized } \\
\hline Mean & 0.525 & 0.460 & 0.459 & 0.455 & 0.468 & 0.506 & 0.484 \\
\hline Median & 0.511 & 0.450 & 0.479 & 0.461 & 0.466 & 0.498 & 0.48 \\
\hline $\mathrm{N}$ & 34 & 38 & 46 & 53 & 65 & 66 & 61 \\
\hline \multicolumn{8}{|l|}{ New firms } \\
\hline Mean & 0.568 & 0.568 & 0.467 & 0.528 & 0.58 & 0.575 & 0.493 \\
\hline Median & 0.557 & 0.569 & 0.453 & 0.446 & 0.5526 & 0.558 & 0.53 \\
\hline $\mathrm{N}$ & 29 & 25 & 31 & 24 & 27 & 25 & 22 \\
\hline \multicolumn{8}{|l|}{ State } \\
\hline \multicolumn{8}{|l|}{ Privatized } \\
\hline Mean & 0.849 & 0.796 & 0.495 & 0.391 & 0.384 & 0.338 & 0.324 \\
\hline Median & 0.999 & 0.999 & 0.503 & 0.315 & 0.349 & 0.292 & 0.275 \\
\hline $\mathrm{N}$ & 43 & 44 & 19 & 21 & 17 & 16 & 13 \\
\hline \multicolumn{8}{|l|}{ New firms } \\
\hline Mean & 0.667 & 0.669 & 0.645 & 0.602 & 0.751 & 0.513 & 0.513 \\
\hline Median & 0.775 & 0.780 & 0.780 & 0.667 & 0.751 & 0.513 & 0.513 \\
\hline $\mathrm{N}$ & 3 & 3 & 3 & 3 & 2 & 1 & 1 \\
\hline
\end{tabular}




\section{Table 6: Determinants of ownership concentration: OLS estimates}

The table shows the regression results of ownership concentration in the sample of non-financial firms listed on the Warsaw Stock Exchange, measured by the logistic transformation of the percentage voting rights held by the largest shareholders (Lvote1), on the set of explanatory variables. See table 2 for the definition of other variables. All regressions include a constant term and year fixed effects.. Robust standard errors are presented in parentheses. Significance at the $1 \%, 5 \%$, and $10 \%$ level is denoted $* * *, * *$, and $*$, respectively.

\begin{tabular}{|c|c|c|c|c|c|c|c|c|}
\hline Variables & $\begin{array}{l}A / l \\
(1)\end{array}$ & $\begin{array}{l}A / l \\
(2)\end{array}$ & $\begin{array}{l}A / l \\
(3)\end{array}$ & $\begin{array}{l}A / l \\
(4)\end{array}$ & $\begin{array}{l}A / l \\
(5)\end{array}$ & $\begin{array}{c}\text { New } \\
(6)\end{array}$ & $\begin{array}{c}\text { Privatized } \\
\text { (7) }\end{array}$ & $\begin{array}{c}\text { Privatized } \\
\text { (8) }\end{array}$ \\
\hline Firm size & $\begin{array}{c}0.254 \\
(0.041)^{* * *}\end{array}$ & $\begin{array}{l}0.148 \\
(0.043) * * *\end{array}$ & $\begin{array}{c}0.138 \\
(0.044)^{* * *}\end{array}$ & $\begin{array}{c}0.144 \\
(0.033)^{* * *}\end{array}$ & $\begin{array}{c}0.143 \\
(0.033)^{* * *}\end{array}$ & $\begin{array}{c}0.128 \\
(0.059)^{* * *}\end{array}$ & $\begin{array}{c}0.169 \\
(0.043)^{* * *}\end{array}$ & $\begin{array}{c}0.186 \\
(0.044)^{* * *}\end{array}$ \\
\hline Profitability & $\begin{array}{l}-0.022 \\
(0.023)\end{array}$ & $\begin{array}{c}0.014 \\
(0.022)\end{array}$ & $\begin{array}{l}-0.014 \\
(0.022)\end{array}$ & $\begin{array}{l}-0.008 \\
(0.015)\end{array}$ & $\begin{array}{l}-0.008 \\
(0.015)\end{array}$ & $\begin{array}{l}-0.030 \\
(0.063)\end{array}$ & $\begin{array}{l}-0.013 \\
(0.015)\end{array}$ & $\begin{array}{l}-0.018 \\
(0.015)\end{array}$ \\
\hline $\begin{array}{l}\text { Volatility } \\
\text { (std) }\end{array}$ & $\begin{array}{c}0.151 \\
(0.070)^{* *}\end{array}$ & $\begin{array}{c}0.152 \\
(0.065)^{* * *}\end{array}$ & $\begin{array}{c}0.156 \\
(0.065)^{* *}\end{array}$ & $\begin{array}{c}0.214 \\
(0.050)^{* * *}\end{array}$ & $\begin{array}{c}0.207 \\
(0.050)^{* * *}\end{array}$ & $\begin{array}{c}0.268 \\
(0.096)^{* * *}\end{array}$ & $\begin{array}{c}0.231 \\
(0.066)^{* * *}\end{array}$ & $\begin{array}{c}0.190 \\
(0.066)^{* *}\end{array}$ \\
\hline $\begin{array}{l}\text { Volatility } \\
\text { (variance) }\end{array}$ & $\begin{array}{l}-0.005 \\
(0.004)\end{array}$ & $\begin{array}{l}-0.005 \\
(0.004)\end{array}$ & $\begin{array}{l}-0.005 \\
(0.004)\end{array}$ & $\begin{array}{c}-0.007 \\
(0.003) * * *\end{array}$ & $\begin{array}{c}-0.007 \\
(0.003) * * *\end{array}$ & $\begin{array}{c}-0.009 \\
(0.005)^{*}\end{array}$ & $\begin{array}{c}-0.009 \\
(0.005)^{*}\end{array}$ & $\begin{array}{l}-0.007 \\
(0.005)\end{array}$ \\
\hline Years of listing & & $\begin{array}{c}-0.229 \\
(0.028)^{* * *}\end{array}$ & $\begin{array}{c}-0.235 \\
(0.028)^{* * *}\end{array}$ & $\begin{array}{c}-0.175 \\
(0.022) * * *\end{array}$ & $\begin{array}{c}-0.174 \\
(0.022) * * *\end{array}$ & $\begin{array}{c}-0.191 \\
(0.052) * * *\end{array}$ & $\begin{array}{c}-0.153 \\
(0.026) * * *\end{array}$ & $\begin{array}{c}-0.124 \\
(0.027)^{* * *}\end{array}$ \\
\hline Intangibles & & & $\begin{array}{c}-3.266 \\
(1.583)^{* *}\end{array}$ & $\begin{array}{c}-3.511 \\
(1.255)^{* * *}\end{array}$ & $\begin{array}{c}-2.772 \\
(1.278)^{* *}\end{array}$ & $\begin{array}{c}-3.857 \\
(1.912)^{* *}\end{array}$ & $\begin{array}{c}-0.223 \\
(0.1 .922)\end{array}$ & $\begin{array}{l}-0.193 \\
(1.915)\end{array}$ \\
\hline Tobin’s Q (t-1) & & & & $\begin{array}{c}0.041 \\
(0.053)\end{array}$ & $\begin{array}{c}0.078 \\
(0.056)\end{array}$ & $\begin{array}{c}0.052 \\
(0.092)\end{array}$ & $\begin{array}{c}0.020 \\
(0.081)\end{array}$ & $\begin{array}{c}0.058 \\
(0.081)\end{array}$ \\
\hline $\begin{array}{r}\text { mpp } \\
\text { embo } \\
\text { IPO }\end{array}$ & & & & & & & & $\begin{array}{c}0.311 \\
(0.135)^{* *} \\
-0.220 \\
(0.137) \\
-0.269 \\
(0.129)^{* *}\end{array}$ \\
\hline $\begin{array}{l}\text { Type of owner } \\
\text { media and utilities }\end{array}$ & $\begin{array}{l}\text { no } \\
\text { no }\end{array}$ & $\begin{array}{c}\text { yes } \\
\text { no }\end{array}$ & $\begin{array}{c}\text { yes } \\
\text { no }\end{array}$ & $\begin{array}{c}\text { yes } \\
\text { no }\end{array}$ & $\begin{array}{l}\text { yes } \\
\text { ves }\end{array}$ & $\begin{array}{l}\text { yes } \\
\text { yes }\end{array}$ & $\begin{array}{l}\text { yes } \\
\text { yes }\end{array}$ & $\begin{array}{l}\text { yes } \\
\text { yes }\end{array}$ \\
\hline $\mathrm{R} 2$ & 0.090 & 0.221 & 0.224 & 0.254 & 0.258 & 0.207 & 0.328 & 0.343 \\
\hline $\mathrm{N}$ & 1185 & 1185 & 1185 & 1002 & 1002 & 297 & 705 & 705 \\
\hline
\end{tabular}




\section{Table 7: Ownership concentration and firm value: OLS and 2SLS}

The table shows the regression results for Tobin's Q in the sample of non-financial firms listed on the Warsaw Stock Exchange. Lvote1 is the logistic transformation of the percentage voting rights held by the largest shareholders. See table 2 for the definition of other variables. All regressions include time fixed effects, dummies for media, utilities and high tech industries, dummies for the type of the largest owner and constant term. Dummies for privatization methods are included in regressions for all and privatized firms. Standard errors are presented in parentheses. Significance at the $1 \%, 5 \%$, and $10 \%$ level is denoted $* * *, * *$, and $*$, respectively.

\begin{tabular}{|c|c|c|c|c|c|c|c|}
\hline Variables & $\begin{array}{l}\text { All } \\
\text { OLS } \\
(1)\end{array}$ & $\begin{array}{c}\text { All } \\
\text { OLS } \\
(2)\end{array}$ & $\begin{array}{c}\text { New } \\
\text { OLS } \\
(3)\end{array}$ & $\begin{array}{c}\text { Privatized } \\
\text { OLS } \\
\text { (4) }\end{array}$ & $\begin{array}{c}A / l \\
2 S L S \\
(5)\end{array}$ & $\begin{array}{c}\text { New } \\
2 S L S \\
(6)\end{array}$ & $\begin{array}{c}\text { Privatized } \\
\text { 2SLS } \\
\text { (7) }\end{array}$ \\
\hline \multirow[t]{2}{*}{ Lvote1 } & 0.025 & 0.028 & 0.032 & 0.025 & 0.975 & 0.749 & 0.497 \\
\hline & $(0.013)^{*}$ & $(0.013)^{* *}$ & $(0.037)$ & $(0.011)^{* *}$ & $(0.229)^{* * *}$ & $(0.338)^{* *}$ & $(0.168)^{* * *}$ \\
\hline \multirow[t]{2}{*}{ Firm size } & -0.014 & -0.024 & -0.071 & 0.012 & -0.102 & -0.099 & -0.043 \\
\hline & $(0.018)$ & $(0.018)$ & $(0.037)^{* *}$ & $(0.019)$ & $(0.039)^{* * *}$ & $(0.054)^{*}$ & $(0.034)$ \\
\hline \multirow[t]{2}{*}{ Current profitability } & -0.038 & -0.037 & -0.036 & -0.039 & -0.022 & -0.050 & -0.029 \\
\hline & $(0.010)^{* * *}$ & $(0.009)^{* * *}$ & $(0.047)$ & $(0.007)^{* * *}$ & $(0.017)$ & $(0.065)$ & $(0.010)^{* * *}$ \\
\hline \multirow[t]{2}{*}{ Years of listing } & -0.006 & -0.012 & -0.071 & 0.006 & 00.129 & 0.091 & 0.068 \\
\hline & $(0.014)$ & $(0.014)$ & $(0.035)^{*}$ & $(0.013)$ & $(0.044)^{* * *}$ & $(0.087)$ & $(0.027)^{* * *}$ \\
\hline \multirow[t]{2}{*}{ Intangibles } & -0.305 & 0.057 & 0.635 & -0.752 & 3.157 & 3.344 & -0.560 \\
\hline & $(0.737)$ & $(0.731)$ & $(1.311)$ & $(0.921)$ & $(1.562)^{* *}$ & $(2.331)$ & $(1.239)$ \\
\hline \multirow[t]{2}{*}{ Foreign 20} & 0.170 & 0.156 & 0.311 & 0.078 & -0.596 & -0.377 & -0.257 \\
\hline & $(0.063)^{* * *}$ & $(0.062) * * *$ & $(0.172)^{*}$ & $(0.055)$ & $(0.208)^{* * *}$ & $(0.385)$ & $(0.135)^{*}$ \\
\hline \multirow[t]{2}{*}{ Initial profitability } & & 0.683 & 0.798 & 0.576 & 0.817 & 0.547 & 0.567 \\
\hline & & $(0.127)^{* * *}$ & $(0.240)^{* * *}$ & $(0.155)^{*}$ & $(0.257)^{* * *}$ & $(0.365)$ & $(0.168)^{* * *}$ \\
\hline F-stat $1^{\text {st }}$ stage & & & & & $\begin{array}{c}7.75 \\
(0.000)\end{array}$ & $\begin{array}{c}3.10 \\
(0.03)\end{array}$ & $\begin{array}{c}5.00 \\
(0.002)\end{array}$ \\
\hline R2 & 0.254 & 0.273 & 0.264 & 0.235 & . & . & . \\
\hline $\mathrm{N}$ & 1185 & 1185 & 365 & 820 & 1002 & 297 & 705 \\
\hline
\end{tabular}




\footnotetext{
${ }^{1}$ See a recent paper by Helwege et al. (2005). Exploring what makes US firms becoming widely held over time they find that variables motivated by agency theory are weak in explaining the evolution of ownership and stock market variables are important.

${ }^{2}$ Carlin and Mayer (2003) examine the possibility that firms in some industries may require specific types of ownership and control. Rajan and Zingales (2000) argue that the theory of the firm should be revisited because of a significant structural movement towards the importance of human capital, at the expense of other, more tangible assets.

${ }^{3}$ Demsetz (1983) considers that one of the costs of concentrated ownership is the disincentive effect of monitoring. Positive trade-off between uncertainty and incentives in the context of pay-for-performance contracts is analyzed by Prendergast (2002). He argues that contrary to the standard prediction of agency theory, firms delegate decision-making power more in uncertain environments. It happens because a principal may have little idea what the right kinds of effort in such cases are and the marginal returns to delegation are likely to be higher in more uncertain environments.

${ }^{4}$ Bolton and von Tadden (1999) argue that the value of monitoring may influence the degree of ownership concentration.

${ }^{5}$ Intangibles include R\&D expenditures, patents, brands, goodwill and any other nonmonetary assets without physical substance.

${ }^{6}$ Moral hazard theories predict that in firms with more soft assets there is more scope for discretionary spending, so this variable should positively affect ownership concentration. In order to take into account the possibility that more volatility in firm's environment increases the value of monitoring, in the regressions for ownership concentration I will also include a proxy for firm idiosyncratic risk.

${ }^{7}$ For the review of the literature see Shleifer and Vishny (1997).

${ }^{8}$ Also see Hermalin and Weisbach (1991)

${ }^{9}$ Hausman test does not allow using random instead of fixed effects.

${ }^{10}$ Additional arguments comes from Pindado and de la Torre (2004) who tried to identify the main source of endogeneity of ownership and found that that, in a sample of Spanish firms, it is rather due to the simultaneity between ownership and firm value than to unobservable heterogeneity.

${ }^{11}$ Kahn and Winton (2002) predict a negative correlation between firm performance and ownership concentration.

${ }^{12}$ I do not include banks and other financial companies because they have specific problems of valuation and regulation, which would make the comparison difficult.

${ }^{13}$ See Glaeser et al. (2001) for the description of the stringent regulation of the securities market in Poland.

${ }^{14}$ For details of the National Investment Funds program see Grosfeld and Hashi (2005).

15 Helwege et al. (2005) show that US companies' ownership also becomes less concentrated following their IPO.

${ }_{16}$ The information provided in tables 4 and 5 should be taken with caution as the sample changes across years. We do not know to what extent changes in ownership concentration are driven by changes in the sample or by changes within firms.

${ }^{17}$ Let us note that the equity holdings of the state in 'new firms' seem high but these numbers concern a very limited number of firms (1-3).

${ }^{18}$ As size will also be included in the regression for Tobin's Q, I use sales rather than assets to avoid a spurious correlation with the denominator of Tobin's Q (see Loderer and Martin, 1997).

${ }^{19}$ See, for instance, Himmelberg et al. (1999)

${ }^{20}$ Kole (1994) provides evidence of a reverse causality: performance affects ownership rather than the other way round.

${ }^{21}$ In a recent paper, Boubakri et al. (2005) include privatization method in their estimation of cross-firm differences in ownership concentration.

${ }^{22}$ Such logistic measure is currently used in the literature (see for instance Demsetz and Lehn, 1985, and Himmelberg et al., 1999). It converts a bounded number (the simple percentage measure which varies from 0 to $100 \%$ ) to an unbounded figure.

${ }^{23}$ The results of separate regressions for the early and late years of listing confirm this hypothesis (results available on request).
} 
${ }^{24}$ The hypothesis that the difference between cash flow rights and control rights is associated with a lower firm value was considered, for instance, by Shleifer and Vishny (1997).

${ }^{25}$ The use of dual-class shares is much more frequent in new than in privatized firms: the average value of the dummy variable indicating the use of dual-class shares is 0.58 in the case of new firms and 0.22 in the case of privatized firms. It is likely that using dual class shares, the initial founders of the 'new' firms try to preserve greater degree of control than the allocation of cash flow rights would guarantee.

${ }^{26}$ I only present the results of the second stage, as the estimates of the first equation were already discussed. However, at the bottom of table 7, I report F-statistics for the first stage of the regressions.

${ }^{27}$ However, Klapper et al. (2005), looking for the impact of foreign owners on the improvement of corporate governance standards, found that foreign investors do not significantly differ from domestic owners.

${ }^{28}$ A similar result was obtained by Gugler and Weigand (2003). 